\title{
THE IMPACT OF AUGMENTED REALITY ON LEARNERS' MOTIVATION IN A READING CLASSROOM AND RELATED PROBLEMS
}

\author{
Le Thi Khanh Linh* \\ TNU - School of Foreign Languages
}

\section{ABSTRACT}

Augmented reality, one of the latest technologies implemented in education, has gained its reputation as a classroom motivational trigger, particularly in language classrooms. Though the advantages of augmented reality in educational settings are undeniable, it still has several downsides. The purpose of this research is to examine learners' evaluation upon the impact of augmented reality on their learning motivation in a reading classroom, and difficulties they have to face when experiencing AR in their class. Two research questions were formulated, regarding the students' learning motivation prior to and after the use of augmented reality and related problems in their reading classroom. Data from pre-usage and post-usage questionnaires developed based on the Instructional Materials Motivation Survey show that the students' learning motivation was significantly increased after the intervention of augmented reality in their classroom. Also, results from the end-line questionnaire and semi-structured interviews revealed typical problems arising during the use of augmented reality, with technical problems appearing to be of the biggest concern. It is hoped that these results would benefit teachers in the inclusion of augmented reality in their language classes and facilitate students' learning process.

Keywords: foreign language teaching; reading; augmented reality; motivations; problems

Received: 05/02/2020; Revised: 24/02/2020; Published: 28/02/2020

\section{TÁC ĐộNG CỦA TƯơng TÁC THỰC TẾ TỚI ĐộNG LỰC HỌC TẬP CỦA SINH VIÊN TRONG MÔN ĐỌC VÀ NHỬNG VẤN ĐỂ LIÊN QUAN}

\author{
Lê Thị Khánh Linh* \\ Khoa Ngoại ngũu - ĐH Thái Nguyên
}

\section{TÓM TẮT}

Tương tác thực tế đã trở thành một trong những ứng dụng công nghê mới nhất trong giáo dục, đặc biệt là trong dạy và học ngôn ngữ. Mặc dù có những lợi thế nổi bật, tương tác thực tế vẫn tồn tại nhiều bất cập. Vì vậy nghiên cứu này được thực hiện nhằm tìm hiểu xem sinh viên đánh giá như thế nào về tác động của tương tác thực tế đối với động lực học tập của mình trong lớp học kỹ năng đọc, và các khó khăn các em gặp phải với tương tác thực tế. Nghiên cứu tập trung trả lời hai câu hỏi nghiên cứu về động lực học tập của sinh viên trước và sau khi tương tác thực tế được dùng trong lớp và những trở ngại khi học với tương tác thực tế. Số liệu được thu thập thông qua câu hỏi khảo sát trước và sau khi tương tác thực tế được dùng trong lớp và phỏng vấn. Kết quả khảo sát trước và sau khi áp dụng tương tác thực tế trong lớp học cho thấy sau khi được học với tương tác thực tế, động lực học tập của sinh viên đã tăng lên rõ rệt. Đồng thời kết quả khảo sát cuối giai đoạn và phỏng vấn chỉ ra các khó khăn khi sử dụng tương tác thực tế trong lớp, đặc biệt là vấn đề kỹ thuật. Hy vọng rằng, những kết quả này sẽ giúp giáo viên và sinh viên sử dụng tương tác thực tế hiệu quả hơn trong lớp học của mình.

Từ khóa: giảng dạy ngoại ngũu; kỹ năng đọc; tuoong tác thực tế; động lực; vấn đề

Ngày nhận bài: 05/02/2020; Ngày hoàn thiện: 24/02/2020; Ngày đăng: 28/02/2020

Email: lekhanhlinh.sfl@tnu.edu.vn

DOI: https://doi.org/10.34238/tnu-jst.2020.03.2592 


\section{Introduction}

The rapid development of modern technology not only affects various aspects of life but also exercises significant impact on educational practices. The increasing use of technology in classrooms has activated learners' different senses in learning process and created favorable conditions for teachers to transform their teaching methodologies. A large body of research has claimed that teaching and learning can be enhanced with the help of computer - generated technology compared to those without such aids [1].

Augmented reality (AR) is considered as one of the latest technology applied in educational context. Though the history of AR can be traced back to the 1950s with the introduction of a simulator called Sensorama [2], AR truly began to gain researchers' and developers' attention four decades later and it was not until recent years that its growth was of significance [2]. In a simple sense, AR can be understood as a technology that allows users to see the real world by superimposing virtual objects upon the real world [3], [4]. This digital achivement is characterized by the combination of real - world and virtual elements, its real - time interactivity and the $3 \mathrm{D}$ registration [3], [5].

The application of AR represents a breakthrough in education and benefits teaching and learning in a number of ways. For example, authenticity and connections between the experience and the real world are mentioned as critical advantages of AR in education [2], [4]. Furthermore, educators are enthusiastic about the positive impacts of AR on students' satisfaction, knowledge construction, and learning tasks that require spatial ability, team work and experimentation [6]. Especially, AR - based tasks are believed to manipulate learners' motivation, which has a clear link with their academic performance and learning outcomes.
When it comes to language teaching and learning, AR proves its cutting - edge ability to transform traditional classrooms. However, the amount of current research about AR appears not to equal the potentials that this method can offer and many problems associated with the use of AR in language classrooms have not been uncovered from real practices. Moreover, teachers and reseachers tend to focus on the effects of AR on teaching and learning vocabulary and relatively little attention has been paid to explore how AR can be implemented to improve language skills [7]. For these reasons, this paper aims to assess the AR application in a reading classroom, particularly by answering the following two research questions:

1. What are the differences in learners' learning motivation before and after applying $\mathrm{AR}$ in their reading classroom?

2. What are the major problems with the use of AR in the reading class?

Hopefully, the results of the paper would provide more insights into the benefits as well as challenges of using $\mathrm{AR}$ in language classrooms and propose guidelines to maximize the potentials of this technology.

\section{Methods}

\subsection{Participants}

The participants of the study are 38 third year English majors at School of Foreign Languages, Thai Nguyen University. Aged from 20 to 22, they have been learning English for about nine years and their English proficiency ranges from intermediate to upper-intermediate levels. At the time of the research, they were attending the fifteen week English Written Proficiency course which deals with TOEFL iBT reading questions and review writing. The reading section of the course amounts to two periods (100 minutes) every weekly lesson and aims at familiarizing learners with TOEFL iBT 
questions types and improving their reading skills with academic texts. The class materials is the coursebook compiled by the school teachers, consisting of nine chapters that correspond to nine types of questions in TOEFL iBT reading tests and four intensive practice tests.

\subsection{Action research}

This study was conducted with the cycle adopted from Ferrance (2000) which consists of four phrases, namely planning, acting, observing and reflecting [8].

In the initial step, the researcher recognized the drawbacks of traditional reading classroom where learners are bored with pages full of words through the first six weeks of the course. Therefore, a plan to provide AR integrated materials in the lessons was made and a brief instruction of installing and using the selected AR app (HP Reveal) was delivered.

Subsequently, the AR app was implemented in the reading classroom in the next six weeks. The teacher designed a $15-20$ minute activity for each class to introduce new words of the texts, test students' comprehension or lead them to the new lesson. Due to the limited Internet access, the students were required to work in groups of three or four to share the app in the activites.

In the next step, the gain from the use of the AP app was observed through out the action research procedure. The data collected from preusage and postusage questionnaires indicate the possible changes in students' motivation before and after the AR app was used while the endline questionnaire and semi - structured interviews reveal obstacles they met during the intervention.

Finally, at the end of the six - week intervention, the AR app was evaluated and the obstacles that arose from the action were identified for further improvements.

\subsection{Data collection instruments}

\subsubsection{Preusage and postusage questionnaires}

The preusage and postusage questionnaires that examine learners' motivation were adapted from the Instructional Materials Motivation Survey (IMMS), which is a 36item situational measure of people's responses to instructional materials in the light of the Attention, Relevance, Confidence and Satisfaction (ARCS) Model, as suggested by Keller [9]. According to the ARCS model, a material should draw learners' attention, be relevant to them, make them feel confident with the material content and satisfied after working with the material.

Of the four factors in the model, attention is believed to be the most important one as it triggers learners' motivation, which activates their willingness to invest their time and devote their effort [10]. Attention can be gained either perceptually or inquisitively. While perceptual arousal results from innovative and astonishing events, inquiry arousal is initiated by learners' curiosity to challenging questions or problems [9], [10]. In the questionnaires, twelve out of the 36 items were for examining learners' attention.

As an important factor contributing to learners' learning motivation, relevance was asked in nine questions in the questionnaires. Relevance can be achieved when linguistic use and examples are familiar to the students [9], [10]. In the model, six principal strategies are mentioned to establish relevance in classrooms, namely experience, present worth, future usefulness, needs matching, modelling and choice [9].

Another component of the model is confidence, which means establishing positive expectations for gaining success among students. Confidence can be built in a number of ways. For example, a syllabus with clearly stated grading policy, rubrics or time allowance to complete the tasks can help to 
raise learners' confidence. Moreover, they can feel more confident when they receive relevant feedback or recognize their own improvements [9]. There were nine questions related to confidence in the questionnaires.

Finally, the remaining six questions were to explore how satisfied learners are with their learning experiences, which can be obtained from a sense of achievement, praise, or entertainment [9]. Keller also claims that immediate application of their newly learned skills can motivate learners significantly.

Based on the ARCS model, the IMMS was constructed to measure learners' learning motivation. In the form of a five - point Likert scale, the IMMS has been validated with the documented reliability coefficient of 0.96 [9] and effectively employed in various studies [11], [12]. In the current study, the preusage questionnaire delivered in the sixth week of the course was the same as the original IMMS while the terminology of AR was inserted in the postusage questionnaire, which was completed six weeks later, after the use of AR.

\subsubsection{Endline questionnaire}

After the learners experienced the activities aided by HP Reveal in six weeks, the endline questionnaire was administered in order to identify difficulties that the users had to face with the app. The questionnaire was comprised of ten five - point items related to the three potential problems with the use of AR in language classrooms, including technical, management and sociocultural factors. The technical issues are verified by three items about the availability of Internet access, app installation and app ease of use. Sociocultural concerns including sharing the app with the others, rights to approach the app equally and teacher's knowledge about the app are questioned in the other three items. The last four items were used to identify how well the classroom was managed when AR was present in the reading lessons.

\subsubsection{Semi - structured interviews}

As a rich source of specific information and details, semi - structured interviews were used to seek for the students' further opinions about the employment of AR in their course, particularly the obstacles they had to face. Five students agreed to take part in the interviews online which lasted approximately eight minutes each. The interviews involved three major questions about the learners' general evaluation about AR in their course, the difficulties they met and necessary changes to exploit AR more effectively.

\section{Results and discussion}

In this section, data generated from the research instruments would help to find the answers to the two research questions respectively. First, the changes in the students' motivation with the AR intervention will be investigated. Subsequently, the negative factors with the use of AR in the course were identified for later improvements.

\subsection{Students' learning motivation before and} after applying $A R$ in their reading classroom

Results from the instrument IMMS uncover how the students perceived their learning motivation when they worked with the course book compared to that when AR was utilized. While the mean score of the preusage questionnaire is 2.69 , that of the postusage one is $15.2 \%$ higher, at 3.45 . The paired samples $\mathrm{t}$ - test was operated to examine the significance of the differences of these two mean scores, as displayed in Table 1.

The value of sig. $=0.000<0.05$ indicates the mean scores of the preusage and postusage questionnaires are statistically different. It can be concluded that the students' learning motivation increased significantly after the $\mathrm{AR}$ activities were exercised in their class. 
Table 1. Paired samples $t$-test result between the preusage and postusage questionnaires

\begin{tabular}{|c|c|c|c|c|c|c|c|c|}
\hline & \multicolumn{5}{|c|}{ Paired differences } & \multirow{3}{*}{$\mathbf{t}$} & \multirow{3}{*}{ df } & \multirow{3}{*}{$\begin{array}{c}\text { Sig. } \\
\text { (2-tailed) }\end{array}$} \\
\hline & \multirow[t]{2}{*}{ Mean } & \multirow[t]{2}{*}{$\begin{array}{c}\text { Std. } \\
\text { Devitation }\end{array}$} & \multirow[t]{2}{*}{$\begin{array}{l}\text { Std. } \\
\text { Error } \\
\text { Mean }\end{array}$} & \multicolumn{2}{|c|}{$\begin{array}{l}\text { 95\% Confidence } \\
\text { Interval of the } \\
\text { Difference }\end{array}$} & & & \\
\hline & & & & Lower & Upper & & & \\
\hline $\begin{array}{c}\text { Pair } 1 \\
\text { Preusage - Postusage }\end{array}$ & -767 & .571 & .093 & -.954 & -.579 & -8.283 & 37 & .000 \\
\hline
\end{tabular}

Also, when individual motivational factors are considered, some interesting findings have been found. As indicated in Table 2, before the use of $\mathrm{AR}$, the relevance of the class materials gained the highest score (3.05), followed by attention (2.63). The other two factors, satisfaction and confidence, were evaluated roughly the same, at 2.51 and 2.5 respectively. In the postusage questionnaire, all four factors experienced obvious changes, implying the students' favor for the materials integrated with AR. The biggest distinction is in attention by $23.6 \%$ increase in the postusage questionnaire. This difference is proved to be significant with the paired sample $\mathrm{t}-$ test, in which the value of sig. = $0.000<0.05$, making it the most appreciated factor after the AR application.

It is also interpreted that the students' confidence and satisfaction grew similarly with AR in their course. Both factors went up by $16.8 \%$ with sig. $=0.000<0.05$, just behind the factor of attention. Meanwhile, the participants held the thinking that the course relevance with AR did not vary much from that without the technology application. Despite the slight growth by $1.8 \%$, there is no significant distinction between the values of relevance in the two questionnaires (sig. = $0.332>0.05$ ).

The students' sharing in the semi - structured interviews confirms their preferences for the use of AR in the reading classroom. All of the interviewees stated that $\mathrm{AR}$ added more interest in the lesson and greatly drew their attention, resulting in their curiosity about the lesson content. Besides, one student emphasized that the presence of AR made them feel the class more modern and two others acknowledged the effect of AR on their vocabulary retention.

Overall, the students considered attending reading classroom with $\mathrm{AR}$ as a positive experience. Their learning motivation has increased significantly, especially their attention. This finding echoes previous studies that explores the relation between AR integration and learners' motivation during a course [7] [12]. Therefore, AR should be integrated in reading classrooms, and in other language skill lessons, particularly for getting students' attention.

\subsection{Students' problems with the use of AR in their classroom}

As depicted in Table 3, the result of the endline questionnaire shows that the prominent obstacle in the class with AR involves limited access to the Internet (3.78). This probably caused the second biggest problem in the class, which is the students' inconvenience when they had to share the app with their group members (3.07).

Table 2. ARCS factors in the preusage and postusage questionnaires

\begin{tabular}{ccccc}
\hline & Preusage & Postusage & $\begin{array}{c}\text { Percentage } \\
\text { difference }\end{array}$ & Sig. (2-tailed) \\
\hline Attention & 2.63 & 3.81 & $23.6 \%$ & .000 \\
Relevance & 3.05 & 3.14 & $1.8 \%$ & .332 \\
Confidence & 2.5 & 3.34 & $16.8 \%$ & .000 \\
Satisfaction & 2.51 & 3.35 & $16.8 \%$ & .000 \\
\hline
\end{tabular}


Table 3. Mean values of students' problems with the use of AR in their classroom

\begin{tabular}{ll}
\hline \multicolumn{1}{c}{ Problems } & $\begin{array}{c}\text { Mean } \\
\text { values }\end{array}$ \\
\hline Limited Internet access & 3.78 \\
Installation difficulty & 1.78 \\
Not user - friendly app & 1.65 \\
Inconvenient app sharing & 3.07 \\
Lack of equal access to content & 2.10 \\
Teacher's limited app knowledge & 2.02 \\
Chaotic class & 2.65 \\
Lack of focus while moving & 2.81 \\
Teacher's unclear instruction & 1.55 \\
Teacher's limited management & 3.10 \\
\hline
\end{tabular}

Another matter of concern is associated with the class management. The students seemed to believe that the teacher could not control what they were doing with the app (3.1). Besides, the learners claimed that when the AR activities were being carried out, they appeared to lose their concentration (2.81) and the class became chaotic (2.65). It is also reported that other technical and sociocultural issues were not likely to hinder the learners' performace in their reading lessons.

The semi - structured interviews provide more personal problems from the students when they worked with AR in their course. The first point to consider is that all of the interviewees mentioned the unavailability of the Internet connection as a difficulty during the application of the app. They informed that they did have WiFi routers installed at their school but these devices did not seem to reach very far and the number of users seemed to be limited. As they are not eligible customers of cheap mobile data plans, they expressed their wish for stronger and more stable school WiFi networks.

Due to the insufficient Internet access, the learners were asked to use the app with two or three other classmates. Some respondents stated their problems when they worked in groups, especially when they had to work with wordy overlay.

"Three or four of us had to share one phone. It's $O K$ if the overlay is a picture or a single word. But if it is a text, however short it is, it is not very easy to see."

Student \#1 [Reconstructed from notes] Also, class management emerges as a matter of concern from the participants. The AR based activities required the learners to make physical movements, which might cause uncontrolled time in the class.

"Some of my classmates made use of the time moving around and scanning the papers to talk about unrelated stuff."

Student \#2 [Reconstructed from notes] Besides these obstacles, one student shared that using the app in the classroom was interesting but it was time consuming as well. Within the class time of 100 minutes, she had to do the tasks in rush and felt quite under pressure.

In short, the initial major problem with the use of AR in the reading lessons is largely related to the technical factor of limited Internet connection, resulting in the difficulty in sharing the app. Hence, the very first action is that learner users should be encouraged to share the Internet connection, from individual or school networks, rather than sharing the use of the app.

Furthermore, class management was relatively far from satisfactory, which impeded the learners' concentration and affected the class discipline. The rules of using the app should be established and announced clearly before the app implementation. Additionally, there should be regular formative assessments to ensure the classroom management and raise learners' focus. 


\section{Conclusion}

It can be seen that AR has been proved to be a technology worth trying in reading classes because it exercised a positive impact on the learners' motivation. With the use of AR in the lessons, the students were more stimulated, indicated by the fact that their motivational factors of attention, confidence and satisfaction increased significantly.

However, there still exist certain hindrances when $\mathrm{AR}$ is employed in the language classrooms, principally stemming from technical and managing issues. It is advisable for both teachers and learners to be aware of these obstacles in order to have plausible solutions for better exploitation of AR in reading classes in particular, and other language skill classes in general.

\section{REFERENCES}

[1]. R. Tamim et al., "What Forty Years of Research says about the Impact of Technology on Learning: A Second - Order Meta - Analysis and Validation Study," Educational Research, vol. 81, no. 1, pp. 428, 2011.

[2]. C. S. Yeun, G. Yaoyuneyong, and E. Johnson, "Augmented Reality: An Overview and Five Directions for AR in Education," Journal of Educational Technology Development and Exchange, vol. 4, no. 1, pp. 119-140, 2011.

[3]. R. Azuma, Y. Baillot, R. Behringer, S. Feiner, S. Julier and B. MacIntyre, "Recent Advances in Augmented Reality," Computer Graphics and Applications, vol. 21, no. 6, pp. 34-47, 2001.
[4]. M. Billinghurst and A. Duenser, "Augmented Reality in the classroom," Computer, vol. 45, pp. 56-63, 2012.

[5]. F. Zhou, H. L. Duh and M. Billinghurst, "Trends in augmented reality teaching, interaction and display: A review of ten years in ISMAR," in Mixed and Augmented Relaity, ISMAR 7th IEE/ACM International Symposium, Cambridge, 2007.

[6]. B. Dalgarno and M. J. W. Lee, "What are the learning affordances of 3-D virtual environment?," British Journal of Educational Technology, vol. 41, no. 1, pp. 10-32, 2010.

[7]. H. H. Alsowat, "Breaking down the Classroom Walls: Augmented Reality Effect on EFL Reading Comprehension, Self - Efficacy, Autonomy and Attitudes," Studies in English Language Teaching, vol. 5, no. 1, pp. 1-23, 2017.

[8]. E. Ferrance, Action research. Providence: Northeast and Islands Regional Educational Laboratory at Brown University, 2000.

[9]. I. M. Keller, Motivational Design for Learning and Performance. New York: Springer, 2010.

[10]. S. Malik, "Effectiveness of ACRS Model of motivational design to overcome non completion rate of students in distance education," Turkish Online Journal of Distance Education, vol. 15, no. 2, pp. 194200, 2014.

[11]. D. U. Bolliger, S. Supanakorn and C. Boggs, "Impact of podcasting on students' motivation in the online learning environment," Computer \& Education, vol. 55, no. 2, pp. 714-722, 2010.

[12]. A. Di Serio, M. B. Ibanez and C. D. Kloos, "Impact of an AR system on students' motivation for a visual art course," Computers and Education, vol. 68, pp. 586-596, 2013. 